\title{
ANALISIS MANAJEMEN RANTAI PASOK SUSU SAPI PERAH PADA KOPERASI PE- TERNAK GALUR MURNI DI KECAMATAN SUMBERBARU KABUPATEN JEMBER
}

\author{
Mahlidatul Isnia ${ }^{1}$, Yuli Hariyati ${ }^{2}$ \& Ati Kusmiati ${ }^{3}$ \\ ${ }^{1}$ Mahasiswa Strata Satu (S1) Program Studi Agribisnis Fakultas Pertanian, Universitas Jember \\ ${ }^{2}$ Staf Pengajar Program Studi Agribisnis, Fakultas Pertanian, Universitas Jember \\ email: mahlidatul_isnia@yahoo.com
}

\begin{abstract}
Koperasi Peternak Galur Murni is a business in the field dairy farm that located in the Sumberbaru District, Jember Regency. This research was aimed to determine: (1) identify the product flow, the financial flow and the information flow in supply chain of dairy cattle, (2) the performance in supply chain of dairy cattle, (3) the value added processing of dairy cattle. The research was conducted in Sumberbaru district Jember regency. The research was designed as descriptive and analytical methods. Data analysis tools used are Supply Chain Operation Reference method and value added analysis with Hayami method. The result analysis showed that: (1) there are three flows in supply chain of dairy cattle in Jember Regency, that are the product flow, the financial flow and the information flow that is not optimal, (2) Measuring the performance in supply chain of dairy cattle in the Koperasi Peternak Galur Murni on the Reliability attribute and Responsiveness showed good performance. Then, the Agility attribute, Costs, and Assets show performance is not good. (3) Koperasi Peternak Galur Murni was able to provide a positive added value in the form of processed pasteur milk and yoghurt with the average added value of $R p 5.194,39$ per liter with ratio $28,86 \%$ and processed yoghurt of $R p$. 7.987,78 with ratio $36,31 \%$.
\end{abstract}

Keywords: supply chain, SCOR, Value Added Analysis, Performance dairy.

\section{PENDAHULUAN}

Peternakan sebagai salah satu subsektor dari sektor pertanian merupakan bidang usaha yang sangat penting dalam penyediaan protein hewani dan berperan dalam pembangunan sumber daya manusia (SDM). Hal ini terkait dengan kesiapan subsektor peternakan dalam menyediakan bahan pangan hewani masyarakat, mutlak untuk perkembangan, dan pertumbuhan. Dalam rangka mencapai tujuan pembangunan peternakan yaitu untuk memenuhi kebutuhan gizi, harus diarahkan pada pengembangan peternakan yang lebih maju melalui pendekatan kawasan, penggunaan teknologi tepat guna, efisiensi, produktivitas, dan berkelanjutan (Arjakusuma, dkk, 2013). Salah satu usaha peternakan yang memiliki potensi untuk dibudidayakan oleh peternak yaitu sapi perah. Peternakan sapi perah merupakan usaha budidaya ternak sapi perah dengan tujuan utama menghasilkan susu. Air susu sebagai sumber gizi berupa protein hewani yang memiliki manfaat sangat besar bagi manusia. Susu memiliki kandungan protein cukup tinggi, sehingga sangat menunjang pertumbuhan, kecerdasan dan daya tahan tubuh (AAK, 2012).
Potensi penyerapan produk susu di Jawa Timur cukup tinggi. Sentra-sentra pengembangan sapi perah di Kabupaten Jember mulai terbentuk yaitu di Sumberbaru, terdapat wadah Koperasi Peternak Galur Murni. Dimana Koperasi tersebut merupakan pilot project dalam peternakan susu sapi perah. Jember berpotensi menjadi produsen andalan, namun terdapat kendala dalam beternak sapi perah. Masalah utama pada peternakan sapi perah di Kabupaten Jember adalah bibit, pakan, manajemen pemeliharaan, dan reproduksi (Wirawan, 2015).

Koperasi Perternak Galur Murni merupakan badan usaha yang bergerak di bidang agribisnis, yang bertujuan untuk meningkatkan pertumbuhan ekonomi masyarakat pedesaan. Anggota usaha susu sapi perah di Koperasi Peternak Galur Murni merupakan kelompok peternak sapi yang berasal dari Kecamatan Puger, Rambipuji, Balung, Sumberbaru dan Kelurahan Mangli. Koperasi Peternak Galur Murni berperan sebagai wadah proses pembelajaran, wahana kerja sama, simpan pinjam dan sebagai tempat penampungan hasil susu sapi perah yang berasal dari kelompok peternak yang kemudian akan dipasarkan dan sebagian akan diolah oleh koperasi menjadi susu pasteurisa- 
si dan yoghurt. Peternak akan memasok susu sapi ke tempat penampungan Koperasi Peternak Galur Murni, sebelum masuk ke tempat penampungan susu tersebut akan melalui tahap pengujian kualitas berdasarkan SNI persusuan yang telah ditetapkan. Apabila kualitas susu tersebut tidak memenuhi standart kualitas yang telah ditentukan, maka Koperasi akan melakukan penolakan terhadap produk tersebut. Hal ini menyebabkan kerugian yang dialami oleh peternak. Oleh karena itu diperlukan manajemen rantai pasok susu sapi perah pada koperasi peternak galur murni agar setiap mata rantai yang terlibat tidak mengalami kerugiaan.

Mata rantai yang terlibat dalam rantai pasok susu sapi perah dimulai dari peternak sapi perah, koperasi, industri susu seperti PT. Nestle, Kafe It's Milk, pedagang pengecer dan konsumen akhir. Namun, dalam penelitian ini rantai pasok susu sapi perah dimulai dari peternak, Koperasi Peternakan Galur Murni, Kafe It's Milk, pedagang pengecer dan konsumen akhir. Pengelolaan aliran ini perlu dilakukan agar setiap mata rantai yang terlibat di dalam rantai pasokan tidak dirugikan dan mampu mencapai tujuan yang diinginkan. Sehingga diperlukan sebuah pendekatan pada sistem rantai pasok yaitu berupa pendekatan untuk mengetahui aliran produk, aliran informasi dan aliran keuangan.

Kegiatan rantai pasok susu sapi perah dimulai oleh pemasok yang merupakan mata rantai yang sangat berpengaruh terhadap ketersediaan bahan baku (kualitas dan kuantitas) yang dihasilkan, yang kemudian akan didistribusikan pada mata rantai yang terlibat dalam rantai pasok susu sapi perah di Koperasi. Proses penyampaian produk susu sapi ke Industri persusuan dipengaruhi oleh standart kualitas susu yang telah ditetapkan oleh Industri susu. Umumnya harga susu ditingkat Industri tergolong rendah, sedangkan jumlah produksi dan standart kualitas yang dihasilkan oleh peternak masih tergolong rendah. Hal ini, akan mempengaruhi kinerja mata rantai yang terlibat dalam rantai pasok susu sapi perah. Selain itu, Adanya ketidakpastian permintaan dari konsumen dan ketidakpastian pasokan dari pemasok mengakibatkan implikasi yang sangat besar terhadap kondisi keuangan koperasi. Oleh karena itu diperlukan pengukuran kinerja rantai pasok susu sapi perah di Koperasi Peternak Galur Murni menggunakan metode Supply
Chain Operation Reference (SCOR).

Kinerja rantai pasok juga dapat diukur melalui nilai tambah pada rantai pasok. Dilihat dari karakteristik sifat susu sapi perah yang mudah rusak mengakibatkan kerugian bagi pihak yang terkait. Upaya untuk mengatasi masalah tersebut perlu dilakukan diversifikasi produk yang mampu memberikan nilai tambah produk. Namun, Pengolahan dan pemasaran yang dilakukan oleh Koperasi masih bersifat sederhana. Beberapa pengukuran kinerja rantai pasok pada Koperasi Peternak Galur Murni sangat mempengaruhi dalam pengambilan keputusan mata rantai yang terlibat. Berdasarkan latar belakang tersebut, maka peneliti akan mengkaji beberapa hal terkait dengan aliran produk, aliran informasi, aliran keuangan, kinerja rantai pasokan susu sapi perah dan nilai tambah pada Koperasi Peternak Galur Murni di Kecamatan Sumberbaru Kabupaten Jember.

Adapun tujuan dari penelitian ini adalah untuk mengetahui: (1) aliran produk, aliran keuangan dan aliran informasi susu sapi perah di Koperasi Peternak Galur Murni Kecamatan Sumberbaru Kabupaten Jember, (2) kinerja rantai pasok susu sapi perah di Koperasi Peternak Galur Murni Kecamatan Sumberbaru Kabupaten Jember, (3) nilai tambah pengolahan susu sapi perah di Koperasi Peternak Galur Murni Kecamatan Sumberbaru Kabupaten Jember.

\section{METODE PENELITIAN}

Penentuan daerah penelitian di-laksanakan secara sengaja (purposive method) yaitu di Koperasi Peternak Galur Murni Kecamatan Sumberbaru Kabupaten Jember. Pertimbangannya adalah Koperasi Peternak Galur Murni merupakan tempat penampungan susu sapi yang mempunyai tiga titik penampungan yang berada di Kabupaten Jember dan sebagai pemasok susu sapi di beberapa daerah di Kabupaten Jember dan Industri susu. Selain itu Koperasi Peternak Galur Murni juga melakukan pengolahan terhadap susu sapi perah.

Metode penelitian yang digunakan dalam penelitian ini adalah metode deskriptif dan analitis. Penelitian deskriptif adalah studi untuk menemukan fakta dan fenomena-fenomena kelompok atau individu dengan interpretasi yang tepat dalam memecahkan suatu masalah. Penelitian analitis digunakan untuk menerapkan beberapa analisis yang berkaitan dengan 
penelitian dan menguji hipotesis-hipotesis, metode analitis digunakan dengan cara menyusun data terlebih dahulu (Nazir, 2005).

Metode pengambilan contoh dalam penelitian ini adalah teknik purposive sampling dan snowball sampling. Teknik purposive sampling digunakan untuk pengambilan contoh Koperasi Peternak Galur Murni yang bertempat di Kecamatan Sumberbaru dan Mangli yang merupakan tempat penampungan susu segar dan pengolahan susu segar. Teknik snowball sampling digunakan untuk pengambilan contoh mata rantai yang terlibat dalam proses rantai pasokan susu sapi di Koperasi Galur
Murni Kecamatan Sumberbaru, karena jumlah populasi mata rantai yang terlibat dalam rantai pasokan susu sapi tidak diketahui. Dalam hal ini, sampel pertama berdasarkan informasi dari pemilik Koperasi Peternak Galur Murni, kemudian dari peternak, Kafe It's Milk, pedagang pengecer dan konsumen akhir.

Metode pengumpulan data meng-gunakan data primer dan sekunder. data primer yang dikumpulkan oleh peneliti adalah dengan melakukan observasi, wawancara dan kuisioner. Data primer tersebut dapat diperoleh dari mata rantai seperti peternak, Koperasi Peternak Galur Murni, Kafe It's Milk, pedagang

Tabel 1 Perhitungan Indikator Pengukuran Kinerja Rantai Pasokan Level-1

\begin{tabular}{|c|c|c|c|}
\hline Atribut Kinerja & Indikator Level-1 & Perhitungan & Satuan \\
\hline Reliability & $\begin{array}{l}\text { Pemenuhan pesanan secara } \\
\text { sempurna }\end{array}$ & $\begin{array}{l}\text { (Jumlah pemenuhan pesanan } \\
\text { sempurna / jumlah pesanan kes- } \\
\text { eluruhan) x } 100 \%\end{array}$ & $\%$ \\
\hline Responsiveness & Siklus Pemenuhan Pesanan & $\begin{array}{l}\text { Total siklus waktu (source+- } \\
\text { make+deliver) pemenuhan } \\
\text { pesanan }\end{array}$ & Hari \\
\hline \multirow[t]{4}{*}{ Agility } & $\begin{array}{l}\text { Fleksibilitas atas rantai } \\
\text { pasokan }\end{array}$ & $\begin{array}{l}\text { Fleksibilitas atas source + Flek- } \\
\text { sibilitas atas make + Fleksibili- } \\
\text { tas atas deliver }+\end{array}$ & Hari \\
\hline & $\begin{array}{l}\text { Adaptabilitas atas rantai } \\
\text { pasokan }\end{array}$ & $\begin{array}{l}\text { (Adaptabilitas atas source }+ \\
\text { Adaptabilitas atas make }+ \text { Ad- } \\
\text { aptabilitas atas deliver }+ \text { ) } / 3\end{array}$ & $\%$ \\
\hline & $\begin{array}{l}\text { Adaptabilitas bawah rantai } \\
\text { pasokan }\end{array}$ & $\begin{array}{l}\text { (Adaptabilitas bawah source }+ \\
\text { Adaptabilitas bawah make }+ \\
\text { Adaptabilitas bawah deliver)/3 }\end{array}$ & $\%$ \\
\hline & Nilai resiko keseluruhan & $\begin{array}{l}\text { Total nilai resiko pada semua } \\
\text { kegiatan }\end{array}$ & $\%$ \\
\hline Costs & $\begin{array}{l}\text { Biaya total penyampaian } \\
\text { produk }\end{array}$ & $\begin{array}{l}\text { Biaya perencanaan }+ \text { biaya } \\
\text { pengadaan bahan baku }+ \text { biaya } \\
\text { penyampaian material }+ \text { biaya } \\
\text { produksi }+ \text { biaya manajemen } \\
\text { pesanan }+ \text { biaya pemenuhan } \\
\text { pesanan }+ \text { biaya pengembalian }\end{array}$ & Rupiah \\
\hline \multirow[t]{3}{*}{ Assets } & Siklus cash-to-cash & $\begin{array}{l}\text { Lamanya siklus penerimaan }+ \\
\text { lamanya pejualan stok }+ \text { peri- } \\
\text { ode pengeluaran biaya }\end{array}$ & Haro \\
\hline & $\begin{array}{l}\text { Pengembalian asset tetap } \\
\text { rantai pasokan }\end{array}$ & $\begin{array}{l}\text { (Penerimaaan rantai pasokan - } \\
\text { biaya dikeluarkan) / asset tetap } \\
\text { rantai pasokan }\end{array}$ & $\%$ \\
\hline & Pengembalian modal kerja & $\begin{array}{l}\text { (Penerimaaan rantai pasokan } \\
\text { - biaya dikeluarkan) / (perse- } \\
\text { diaan + piutang - utang) }\end{array}$ & $\%$ \\
\hline
\end{tabular}


pengecer dan konsumen. Data sekunder yang dikumpulkan diperoleh dari Koperasi Peternak Galur Murni, Dinas Peternakan dan Badan Pusat Statistik Kabupaten Jember.

Untuk menjawab permasalahan pertama, tentang sistem manajemen rantai pasok (SCM) yang meliputi aliran produk, aliran finansial dan aliran informasi Koperasi Peternak Galur Murni di Kecamatan Sumberbaru Kabupaten Jember dengan menggunakan metode analisis deskriptif.

Untuk menjawab permasalahan kedua, tentang kinerja rantai pasokan susu sapi perah di Koperasi Peternak Galur Murni menggunakan analisis SCOR (Supply Chain Operatian Reference-Model) versi 11.0. Pengukuran kinerja dapat dilakukan dengan menggunakan matriks level-1 dengan perhitungan indikator-indikator kinerja rantai pasokan susu sapi perah di Koperasi Peternak Galur Murni pada tabel 1.

Pada penelitian ini perusahaan yang dianalisis hanya sampai pada pengukuran kinerja pada business process reengineering, dimana dalam pengukuran kinerja menggunakan analisis SCOR terdapat tiga elemen yang dianalisis yaitu business process reengineering, benchmarking, process measurement. Hal ini dikarenakan perusahaan yang dianalisis hanya satu yaitu dikhususkan pada Koperasi Peternak Galur Murni di Kecamatan Sumberbaru Kabupaten Jember. Oleh karena itu, kegiatan benchmarking atau komparasi juga tidak dapat dilakukan sebab tidak ada kinerja perusahaan yang sejenis yang dapat dijadikan sebagai pembanding, sehingga tidak dapat diketahui rantai pasokan susu sapi perah di Koperasi Peternak Galur Murni memiliki kinerja yang baik atau tidak. Oleh karena itu, penarikan kesimpulan pada penelitian kinerja rantai pasok susu sapi perah di Koperasi Peternak Galur Murni level-1 ini berdasarkan nilai maksimum yang dihasilkan pada masing-masing atribut kinerja. Apabila memiliki nilai maksimum pada atribut kinerja tertentu maka rantai pasokan susu sapi perah di Koperasi Peternak Galur Murni memiliki kinerja yang baik pada atribut kinerja tersebut.

Untuk menjawab permasalahan kedua digunakan analisis nilai tambah yaitu Metode Hayami. Menurut Sudiyono (2002), nilai tambah dapat dinyatakan secara matematik, yaitu: Nilai Tambah $=\mathrm{f}(\mathrm{K}, \mathrm{B}, \mathrm{T}, \mathrm{U}, \mathrm{H}, \mathrm{h}, \mathrm{L})$
Keterangan:

$\mathrm{K}=$ Kapasitas produksi

$\mathrm{B}=$ Bahan baku yang digunakan

$\mathrm{T}=$ Tenaga kerja yang digunakan

$\mathrm{U} \quad=$ Upah tenaga kerja

$\mathrm{H} \quad=$ Harga output

$\mathrm{H} \quad$ = Harga bahan baku

$\mathrm{L}=$ Nilai input (nilai semua korbanan selama proses produksi)

Besarnya nilai tambah karena proses pengolahan yang didapat dan pengurangan biaya bahan baku serta input lainnya terhadap nilai produk yang dihasilkan, tidak termasuk tenaga kerja. Dengan kata lain, nilai tambah menggambarkan imbalan bagi tenaga kerja, modal, dan manajemen

\section{HASIL DAN PEMBAHASAN}

Manajemen Rantai Pasok Susu Sapi perah di Koperasi Peternak Galur Murni Kecamatan Sumberbaru Kabupaten Jember

Pola aliran dalam rantai pasokan susu sapi perah di Koperasi Peternak Galur Murni menunjukkan tiga macam aliran dalam proses rantai pasokan tersebut, yaitu aliran produk aliran keuangan dan aliran informasi. Adapun bentuk rantai pasokan susu sapi perah di Koperasi Peternak Galur Murni di Kecamatan Sumberbaru Kabupaten Jember dapat dilihat pada Gambar 1.

Aliran Produk. Aliran produk merupakan pergerakan suatu barang dari hulu (upstream) ke hilir (downstream). Terdapat dua macam bentuk aliran produk dalam rantai pasokan susu sapi perah di Koperasi Peternak Galur Murni, yaitu aliran produk berupa susu sapi segar dan aliran produk berupa olahan susu sapi. Aliran produk susu sapi (segar) mengalir dari peternak hingga ke tangan konsumen. Aliran produk tersebut dimulai dari peternak sapi perah yang telah menjalin kerjasama dengan Koperasi, yang berada di Kecamatan Sumberbaru, Puger, Balung, Rambipuji dan Kelurahan Mangli. Produk tersebut akan disalurkan ke tiga tempat penampungan Koperasi Peternak Galur Murni yang berada di Kecamatan Sumberbaru, Balung dan Kelurahan Mangli. Sebelum produk tersebut ditampung di koperasi, koperasi melakukan uji standart kualitas susu terlebih dahulu. Koperasi hanya menerima susu sapi yang sesuai dengan SNI dan yang tidak memenuhi standart akan dikembalikan/ ditolak oleh koperasi. 


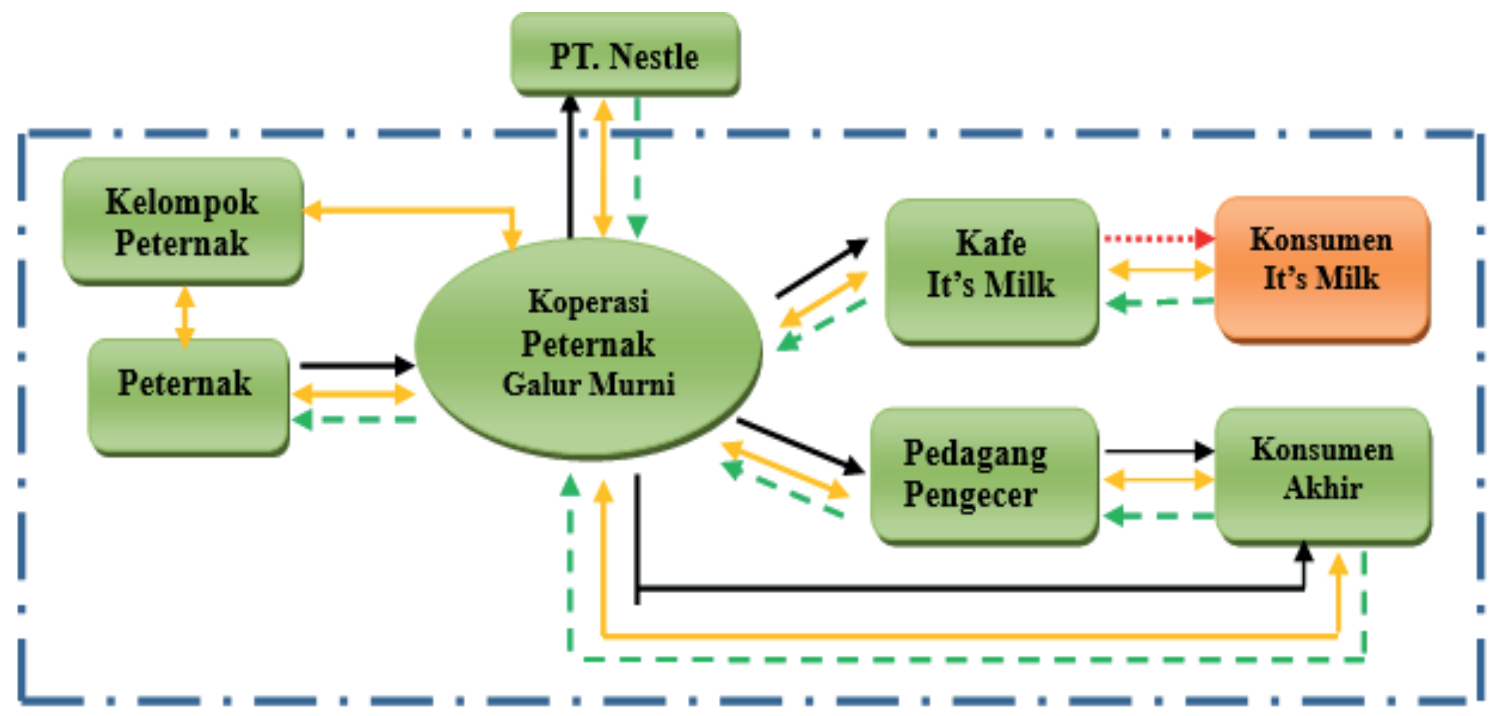

Gambar 1. Pola Aliran dalam Rantai Pasok Susu Sapi Perah di Koperasi Peternak Galur Murni

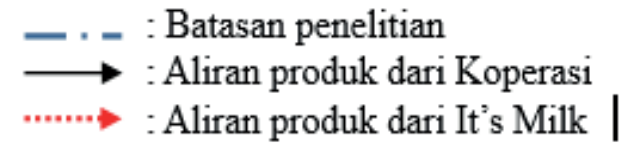

Menurut Septani, dkk (2013), rendahnya kualitas susu yang dihasilkan oleh peternak, yang menyebabkan terjadinya kasus penolakan susu oleh penampung susu Koperasi Unit Desa (KUD) sebelum sampai ke Industri Pengolahan Susu (IPS) dan akhirnya terbuang siasia. Hal ini menyebabkan peternak mengalami kerugian saat susu sapinya ditolak, untuk mengatasi hal tersebut sebagian peternak ada yang mengkonsumsi produk susunya sendiri dan menjual kembali susu yang ditolak kepada penadah/ konsumen.

Penyaluran produk susu sapi yang sudah terkumpul di tempat penampungan susu Koperasi Peternak Galur Murni di Kecamatan Sumberbaru, kemudian akan didistribusikan ke PT. Nestle Indonesia yang berada di Pasuruan. Sedangkan, susu sapi yang telah terkumpul di tempat penampungan Koperasi Kecamatan Balung akan dikirim ke tempat penampungan susu yang ada di Kelurahan Mangli. Kemudian Koperasi Peternak Galur Murni yang ada di Mangli akan mendistribusikan susu sapi ke Kafe It's Milk yang berada di jalan PB Sudirman dan di Ambulu untuk memenuhi kebutuhan bahan baku usahanya. Lembaga lainnya yang terlibat dalam rantai pasokan susu sapi ini yaitu pedagang pengecer, pedagang tersebut melakukan pembelian susu sapi (segar) kemasan kantong plastik ukuran $500 \mathrm{ml}$ dan 250 ml, yang kemudian akan di pasarkan ke konsumen akhir. Pedagang pengecer atau sering disebut loper tersebut mendistribusikan susu

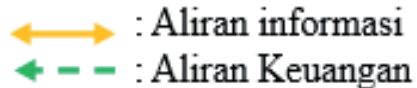

sapi dengan cara keliling. Pedagang pengecer yang berjualan keliling sangat rentan terhadap kerusakan pada produk, karena produk susu sapi tidak bisa bertahan lama tanpa alat pendingin. Apabila susu sapi tidak terjual habis, maka produk tersebut harus disimpan kedalam alat pendingin. Tetapi tidak semua pedagang pengecer mempunyai alat pendingin, sehingga loper akan mengalami kerugian. Adapula pedagang pengecer yang memasarkan susu sapi tersebut di tokonya sendiri yang berada di sekitar lokasi Koperasi. Pedagang pengecer tersebut menjual langsung produknya kepada konsumen, dikarenakan keuntungan yang diperoleh lebih besar. Konsumen yang menjadi target utama pedagang pengecer untuk mendistribusikan produknya adalah ibu rumah tangga dan semua kalangan masyarakat yang berada di sekitar Kabupaten Jember.

Aliran produk olahan susu sapi dimulai dari kegiatan pengolahan yang dilakukan oleh dua mata rantai yaitu Koperasi dan It's Milk. It's Milk melakukan pengolahan susu sapi dalam bentuk susu sapi murni dan pasteurisasi dengan berbagai macam rasa dan disajikan dalam bentuk kemasan, selain itu juga dapat langsung dikonsumsi di kafe Its' Milk. It's Milk menawarkan susu dengan berbagai varian rasa dengan esensi rasa buah. Produk olahan tersebut kemudian akan didistribusikan langsung kepada konsumen. Konsumen yang menjadi target utama adalah anak-anak remaja maupun orang dewasa yang berada disekitar It's Milk serta 
semua kalangan masyarakat. Konsumen dapat membeli dan mengkonsumsi secara langsung produk tersebut di kafe It's Milk yang berada di jalan PB Sudirman dan Ambulu.

Sedangkan aliran produk yang terjadi pada Koperasi Peternak Galur Murni adalah Aliran produk inflow (aliran arah panah menuju Koperasi) merupakan aliran distribusi bahan baku berupa susu sapi dalam bentuk susu segar yang mengalir menuju Koperasi. Selain itu lembaga yang melakukan kegiatan pengolahan susu sapi yaitu Koperasi Peternak Galur Murni, tempat kegiatan pengolahan susu sapi berada di Kelurahan Mangli. Koperasi melakukan kegiatan pengolahan kurang lebih berjalan selama 3 tahun dan sampai sekarang, jadi produk yang dihasilkan masih dalam skala kecil dan belum mendapat ijin badan POM tetapi sudah dalam proses perijinan. Bahan baku berupa susu sapi diperoleh dari peternak yang telah bermitra dengan Koperasi. Koperasi tersebut melakukan pengolahan susu sapi menjadi dua macam produk yaitu susu pasteurisasi dan yoghurt. Kedua produk olahan tersebut dapat diterima oleh masyarakat Jember, karena kedua produk ini memiliki banyak macam rasa yaitu rasa melon, sirsak, strawberi, leci, dan dikemas menggunakan botol serta dalam proses produksinya tanpa menggunakan bahan pengawet. Hal ini, akan membuat produk olahan susu sapi berupa pasteurisasi dan yoghurt masih dapat bersaing dengan produk olahan lain yang dibuat oleh pabrik.

Aliran produk outflow (aliran arah panah keluar Koperasi) merupakan aliran distribusi produk olahan susu sapi berupa pasteurisasi dan yoghurt dari Koperasi Peternak Galur Murni yang keluar atau yang dipasarkan. Aliran produk olahan susu sapi dari Koperasi mengalir keluar menuju pedagang pengecer. Produk olahan berupa pasteurisasi ini dijual dalam kemasan botol ukuran 330 liter dan yoghurt ukuran 250 liter. Pedagang pengecer merupakan lembaga satu-satunya yang berfungsi sebagai lembaga pemasaran produk olahan susu sapi dalam bentuk pasteurisasi dan yoghurt. Pedagang pengecer mendistribusikan produk tersebut dengan cara menjual sendiri produknya di toko dan kantin yang terdapat di sekitar lokasi Koperasi.

Aliran Keuangan. Aliran keuangan merupakan perpindahan uang pembayaran atas jasa atau produk dari setiap mata rantai yang mengalir dari hilir ke hulu. Terdapat enam aliran keuangan yang mengalir dari konsemen akhir hingga ke peternak sapi perah. Aliran keuangan yang mengalir dari Koperasi Peternak Galur Murni ke peternak sapi perah adalah sejumlah uang yang harus dibayarkan oleh pihak Koperasi ke peternak sapi perah atas pembelian susu sapi. Sistem pembayaran dilakukan secara berkala selama 10 hari sekali oleh koperasi, yang telah disepakati oleh peternak. Penentuan harga susu sapi tergantung dari kualitas susunya yang sudah dilakukan kesepakatan diawal menjalin kemitraan oleh koperasi dengan peternak sapi perah. Transaksi pembayaran dilakukan di tempat koperasi.

Aliran keuangan yang mengalir dari It's Milk ke Koperasi Peternak Galur Murni adalah aliran keuangan yang terjadi karena adanya pembelian bahan baku berupa susu sapi oleh pihak It's Milk dari pihak koperasi. Sistem pembayaran dilakukan secara tunai, pembayaran terhadap pembelian susu sapi dilakukan secara langsung dan sesuai permintaan pihak It's Milk setelah susu sapi dikirim oleh koperasi dan sampai ketangan It's Milk. Penentuan harga dilakukan diawal pemesanan yang telah disepakati oleh It's Milk.

Aliran keuangan mengalir dari konsumen produk olahan It's Milk berupa susu sapi murni yang dihidangkan dengan berbagai macam rasa. Sistem pembayaran dilakukan secara tunai, karena konsumen dapat langsung menikmati produk tersebut. Transaksi pembayaran dilakukan langsung di tempat It's Milk setelah melakukan pemesanan.

Aliran keuangan dari pedagang pengecer susu sapi ke Koperasi Peternak Galur Murni dikarenakan adanya transaksi jual beli baik dalam bentuk produk susu sapi dan produk olahan (susu pasteurisasi dan yoghurt) di Koperasi. Sistem pembayaran yang digunakan dalam transaksi ini menggunakan sistem pembayaran tunai, berkala, konsinyasi dan kredit. Sistem pembayaran tunai dilakukan apabila pedagang pengecer membayarkan sejumlah uang secara langsung kepada koperasi. Pembayaran konsinyasi merupakan pembayaran yang dilakukan pedagang pengecer produk susu sapi dan olahan kepada pelaku koperasi setelah produk yang dititipkan oleh pihak koperasi telah terjual seluruhnya maupun sebagian. Sistem pembayaran ini biasanya dilakukan oleh pedagang yang memiliki toko/outlate dan telah menjalin 
kerjasama dengan koperasi. Selain itu sistem pembayaran pada pembeliaan produk susu sapi bisa juga dilakukan secara kredit sesuai dengan kesepakatan antara loper dengan Koperasi. Perbedaan sistem pembayaran ini dipengaruhi oleh kemampuan modal yang dimilki oleh masing-masing pedagang pengecer yang berbeda-beda. Pembayaran dilakukan secara langsung di Koperasi baik setelah melakukan pemesanan maupun tidak.

Aliran keuangan mengalir dari konsumen ke pedagang pengecer produk susu sapi dan olahan berupa susu pasteurisasi dan yoghurt. Sistem pembayaran yang digunakan antara kedua mata rantai ini adalah sistem pembayaran tunai. Aliran keuangan mengalir dari konsumen ke Koperasi Peternak Galur Murni Sistem pembayaran yang digunakan dalam transaksi ini, menggunakan sistem pembayaran tunai. Transaksi pembayaran dilakukan di koperasi langsung, karena konsumen langsung menjemput produknya di koperasi. Koperasi mendapatkan hasil penjualannya setelah produk yang dipesan sudah dalam kemasan.

Aliran Informasi. Aliran informasi merupakan proses komunikasi yang bergerak baik dari hulu ke hilir maupun sebaliknya hilir ke hulu. Aliran informasi dalam rantai pasokan susu sapi perah di Koperasi Peternak Galur Murni, umumnya berkaitan dengan stok susu sapi dan produk olahan yang tersedia, jumlah permintaan produk, informasi harga susu sapi dan produk olahan. Arus informasi dalam rantai pasokan susu sapi di Koperasi Peternak Galur Murni melibatkan semua mata rantai antara lain peternak, Koperasi, It's Milk, pedagang pengecer susu sapi dan produk olahan, serta konsumen akhir. Aliran informasi dalam rantai pasok susu sapi di Koperasi Peternak Galur Murni dibedakan menjadi dua macam aliran informasi yaitu aliran informasi yang mengalir secara vertikal dan secara horizontal. Aliran secara horizontal adalah adanya koordinasi antar sesama anggota mata rantai yaitu aliran informasi sesama kelompok peternak dan sesama peternak dengan cara sharing atau tukar pendapat tentang teknik pemberian pakan sapi perah untuk meningkatkan hasil produksi susu. Terdapat beberapa aliran informasi yang mengalir secara vertikal antar mata rantai dalam rantai pasok susu sapi, antara lain:

Antara kelompok peternak sapi perah dengan Koperasi Peternak Galur Murni. In- formasi yang mengalir dari kelompok peternak ke Koperasi berkaitan dengan kendala-kendala yang dihadapi saat proses budidaya sapi perah. Sedangkan aliran informasi yang mengalir dari Koperasi kepada kelompok peternak sapi perah berkaitan dengan informasi acara penyuluhan.

Antara kelompok peternak dengan peternak sapi perah. Informasi yang mengalir dari kelompok peternak kepada peternak berkaitan dengan acara penyuluhan yang diadakan oleh Koperasi. Sedangkan aliran informasi yang mengalir dari peternak kepada kelompok peternak sapi perah berkaitan dengan kendala-kendala yang dihadapi saat proses budidaya sapi perah.

Antara peternak sapi perah dengan Koperasi Peternak Galur Murni. Informasi yang mengalir dari Peternak kepada Koperasi berkaitan dengan hasil produksi dan penggunaan pakan ternak. Informasi produk berkaitan dengan jumlah hasil produksi susu sapi perah. Aliran informasi yang mengalir dari koperasi kepada peternak sapi perah berkaitan dengan informasi produk, mekanisme transaksi penjualan dan harga. Informasi produk ini, berkaitan dengan ketentuan standart kualitas susu sapi yang telah ditentukan oleh Koperasi. Proses komunikasi dalam menyampaikan informasi antara petani dan koperasi maupun sebaliknya dilakukan dengan dua cara, yaitu dengan cara penyampaiaan informasi secara langsung (tatap muka) dan menggunakan bantuan media komunikasi.

Antara Koperasi Peternak Galur Murni dengan It's Milk. Informasi yang mengalir dari Koperasi ke pihak It's Milk berkaitan dengan informasi harga. Sedangkan informasi yang mengalir dari It's Milk kepada pihak koperasi berkaitan dengan jumlah permintaan susu sapi dan mekanisme transaksi pembelian. Informasi tentang jumlah permintaan susu sapi oleh pihak It's Milk untuk memenuhi kebutuhan bahan baku usaha kafenya. Selain itu, Informasi tentang pengiriman produk berupa susu sapi oleh koperasi langsung ke tempat It's Milk dan pembayaran dilakukan setelah barang sudah sampai di tempat It's Milk.

Antara It's Milk dengan konsumen produk olahan It's Milk. Informasi yang mengalir dari It's Milk dengan konsumen produk olahan It's Milk berupa informasi cara pemesanan produk serta harga jual produk. Informasi tersebut 
diperoleh saat konsumen yang datang untuk mengkonsumsi produk tersebut. Konsumen disambut oleh front-man yang memberikan lembaran menu lengkap dengan daftar harganya kemudian konsumen mengisikan kuantitas item yang hendak dipesan. Sedangkan informasi yang mengalir dari konsumen produk olahan It's Milk ke pihak It's Milk berkaitan dengan jumlah permintaan produk olahan.

Antara Koperasi Peternak Galur Murni dengan pedagang pengecer. Aliran informasi yang mengalir dari Koperasi Peternak Galur Murni ke pedagang pengecer berkaitan dengan informasi produk, harga jual dan mekanisme transaksi penjualan bisa dilakukan dengan cara in order maupun tidak melakukan pemesanan terlebih dahulu. Selain itu aliran informasi juga mengalir antara loper atau pedagang pengecer susu sapi ke pihak Koperasi adalah informasi tentang jumlah permintaan produk susu. Penyampaian Informasi tentang jumlah permintaan produk susu dilakukan dengan dua cara yaitu dengan cara penyampaian informasi secara langsung (tatap muka) dan menggunakan bantuan media komunikasi.

Antara pedagang pengecer dengan konsumen. Informasi yang mengalir dari pedagang pengecer ke konsumen adalah informasi tentang stok produk dan harga. Harga susu sapi dan produk olahan telah ditetapkan oleh pedagang sesuai dengan harga yang berlaku dipasaran dan tidak ada campur tangan sama sekali oleh pihak pemerintah sehingga mekanisme harga diserahkan sepenuhnya pada kondisi pasar. Sedangkan aliran informasi juga terjadi antara konsumen ke pedagang pengecer terkait dengan jumlah permintaan produk susu sapi dan produk olahan. Informasi jumlah permintaan oleh konsumen terbagi menjadi dua yaitu terdapat sebagian konsumen yang melakukan permintaan susu sapi secara berlangganan setiap harinya dan ada pula konsumen yang melakukan permintaan susu sapi dan produk olahan yang tidak menentu. Hal ini menyebabkan pedagang pengecer tidak bisa memperkirakan jumlah stok susu sapi, karena masih terdapat jumlah susu sapi yang tidak terjual, dan harus disimpan di dalam alat pendingin dan dijual keesokan harinya oleh pedagang pengecer. Sehingga koordinasi antara mata rantai susu sapi perah yaitu antara pedagang pengecer dengan konsumen maupun sebaliknya masih belum optimal.
Antara Koperasi Peternak Galur Murni dengan Konsumen. Informasi yang mengalir dari Koperasi Peternak Galur Murni dengan konsumen berupa informasi terkait harga dan produk. Informasi tersebut diperoleh saat konsumen yang datang untuk mengkonsumsi produk tersebut. Sedangkan informasi yang mengalir dari konsumen ke Koperasi Peternak Galur Murni berkaitan dengan jumlah permintaan produk.

Berdasarkan hasil penelitian dapat diketahui bahwa terdapat tiga aliran yaitu aliran produk, aliran keuangan dan aliran informasi dalam rantai pasokan susu sapi perah di Koperasi Peternak Galur Murni. Aliran produk mengalir dari peternak hingga ke konsumen. Namun aliran produk belum berjalan optimal yang ditandai dengan adanya penolakan susu sapi perah oleh Koperasi dan masih adanya produk yang tidak terjual oleh pedagang pengecer. Rendahnya kualitas susu yang dihasilkan oleh peternak akan berberdampak pada keuangan para peternak, dimana aliran keuangan mengalir dari konsumen hingga ke peternak. hal ini dikarenakan aliran informasi terkait dengan kualitas produk belum mampu diserap dengan baik oleh peternak sebagai pemasok bahan baku. Aliran informasi mengalir dua arah dari peternak ke konsumen baik secara vertikal maupun secara horizontal.

\section{Kinerja Rantai Pasokan Susu Sapi Perah di Koperasi Peternak Galur Murni Kecama- tan Sumberbaru Kabupaten Jember}

Pengukuran kinerja rantai pasokan susu sapi perah pada Koperasi Peternak Galur Murni dilakukan untuk mengevaluasi sejauh mana peningkatan kinerja rantai pasok susu sapi perah yang dikehendaki, maka dibutuhkan pengukuran secara kuantitatif yang disebut sebagai metrik-metrik penilaian.

Pengukuran kinerja rantai pasokan susu sapi perah pada Koperasi Peternak Galur Murni dilakukan menggunakan alat analisis Supply Chain Operation Refference (SCOR) versi 11.0. Pengukuran kinerja rantai pasok tersebut dilakukan secara keseluruhan, dimana didalamnya terdapat dua proses kegiatan yaitu proses penyaluran produk peternakan berupa susu sapi perah (segar) dan olahan susu sapi (susu pasteurisasi dan yoghurt). Kegiatan tersebut mencakup proses plan, source, make, deliver, dan return dari pemasok bahan 
Tabel 2. Hasil Analisis Kinerja Rantai Pasokan Produk Susu Sapi dan Olahan (susu pasteurisasi dan voghurt)

\begin{tabular}{|c|c|c|}
\hline Atribut Kinerja & Indikator Level-1 & Hasil \\
\hline Reliability & $\begin{array}{l}\text { Pemenuhan pesanan secara } \\
\text { sempurna }\end{array}$ & $100 \%$ \\
\hline Responsiveness & Siklus Pemenuhan Pesanan & 5 Hari \\
\hline \multirow[t]{4}{*}{ Agility } & $\begin{array}{l}\text { Fleksibilitas atas rantai } \\
\text { pasokan }\end{array}$ & 9 Hari \\
\hline & $\begin{array}{l}\text { Adaptabilitas atas rantai } \\
\text { pasokan }\end{array}$ & $8,33 \%$ \\
\hline & $\begin{array}{l}\text { Adaptabilitas bawah rantai } \\
\text { pasokan }\end{array}$ & $83,33 \%$ \\
\hline & Nilai resiko keseluruhan & $55 \%$ \\
\hline Costs & $\begin{array}{l}\text { Biaya total penyampaian } \\
\text { produk }\end{array}$ & $783.484 .828,-$ \\
\hline \multirow[t]{2}{*}{ Assets } & Siklus cash-to-cash & 22 Hari \\
\hline & $\begin{array}{l}\text { Pengembalian asset tetap } \\
\text { rantai pasok }\end{array}$ & $14,76 \%$ \\
\hline
\end{tabular}

Sumber: Data Primer diolah Tahun 2015

baku hingga ke konsumen akhir. Pengukuran kinerja melalui analisis SCOR dilakukan dengan membagi aspek kinerja yang akan diukur menjadi beberapa bagian yang disebut dengan atribut kinerja. Terdapat lima atribut kinerja yang akan dianalisis pada rantai pasok susu sapi perah yaitu Reliability, Responsiveness, Agility, Cost, dan Assets. Kelima atribut kinerja tersebut nantinya dibagi lagi menjadi bagian yang lebih spesifik untuk mengukur kinerja yang disebut dengan metrik/indikator. Pengukuran kinerja dilakukan menggunakan indikator level-1 dimana dalam perhitungannya dilakukan melalui indikator level-2. Adapun indikator level-1 yang digunakan pada penelitian ini yaitu pemenuhan pesanan sempurna, siklus pemenuhan pesanan, fleksibilitasatas rantai pasokan, adaptabilitas atas rantai pasokan, adaptabilitas bawah rantai pasokan, nilai resiko keseluruhan, biaya penyampaian produk, siklus cash-to-cash, pengembalian aset tetap rantai pasokan, dan pengembalian modal kerja.

Berdasarkan Tabel 2. Menunjukkan bahwa pada kelima atribut kinerja diatas, Koperasi Peternak Galur Murni mampu memenuhi pesanan secara sempurna yaitu $100 \%$ sehingga memiliki kinerja yang baik pada atribut Reliability dan mampu melakukan pengiriman secara tepat waktu pada atribut Responsiveness. Pada atribut Agility, Costs, dan Assets menun- jukkan kinerja yang belum baik.

Atribut Reliability, Koperasi Peternak Galur Murni mampu memenuhi pesanan secara sempurna yaitu $100 \%$ sehingga memiliki kinerja yang baik pada atribut Reliability. Pemenuhan pesanan sempurna dari Koperasi Peternak Galur Murni meliputi indikator pemenuhan pesanan secara kuantitas, ketepatan waktu, akurasi dokumen maupun kesempurnaan barang. Hal ini dikarenakan, Koperasi lebih mendahulukan kebutuhan konsumen dan pedagang pengecer dibandingkan dengan Industri Persusuan, dikarenakan Industri persusuan memberikan penawaran harga yang rendah. Berdasarkan hasil penelitian Usmiati, S dan Abubakar (2009), menyatakan bahwa Koperasi susu di Indonesa mempunyai posisi tawar yang sangat lemah ketika berhadapan dengan IPS, baik dalam hal jumlah penjualan susu, waktu penjualan, dan harga yang diperoleh.

Atribut Responsiveness, pada indikator perhitungan siklus waktu pemenuhan pesanan untuk Koperasi Peternak Galur Murni secara kesuluruhan membutuhkan waktu selama 5 hari. Hal ini menunjukkan bahwa kinerja rantai pasok susu sapi pada atribut kinerja responsiveness adalah baik (tepat waktu sesuai dengan permintaan konsumen). Waktu pengiriman sangat dipertimbangkan dalam penilaian kinerja rantai pasok, Koperasi Peternak Galur Murni 
dalam melakukan pengiriman susu mengacu pada standart pengiriman susu segar. Menurut Misgiyarta dkk (2008), kesalahan metode pengiriman dapat menyebabkan kualitas susu menurun atau bahkan tidak sesuai standar. Susu segar harus segera disetor atau ditransportasikan setelah proses pemerahan selesai agar kualitas susu tetap baik.

Atribut agility, yang terdiri dari empat indikator yang menunjukkan bahwa kemampuan Koperasi dalam menghadapi pengaruh eksternal. Pada indikator fleksibilitas atas rantai pasokan, Koperasi membutuhkan waktu selama 9 hari untuk memenuhi lonjakan permintaan dari konsumen, lamanya waktu tersebut dipengaruhi oleh rendahnya produktivitas susu sapi yang dihasilkan oleh peternak. Hal tersebut juga terjadi pada indikator adaptabilitas atas rantai pasok nilai sebesar 8,33\% tersebut menunjukkan bahwa koperasi mampu meningkatkan jumlah produksi dan pemasaran sebesar 8,33\% atau sebanyak 29.680 liter apabila diberikan waktu selama 30 hari untuk memenuhi lonjakan permintaan yang terjadi. Rendahnya nilai adaptabilitas atas rantai pasokan susu sapi ini disebabkan oleh rendahnya produktivitas susu sapi yang dihasilkan oleh peternak yang menjadi anggota koperasi. Rata-rata peternak menghasilkan susu sapi sebanyak 8-10 liter per ekornya. Selain itu, pada indicator adaptabilitas bawah Koperasi Peternak Galur Murni mampu menangani ketiadaan pesanan hanya $83,33 \%$ selama tiga puluh hari atau dengan kata lain bahwa Koperasi Peternak Galur Murni akan mengeluarkan biaya tambahan ketika pesanan dibatalkan total oleh konsumen dalam rentang waktu 30 hari. Koperasi peternak galur murni akan mengeluarkan biaya tambahan untuk mesin cooling unit sebagai tempat penyimpanan susu. Pada indikator nilai resiko, dimulai proses perencanaan hingga pengembalian produk koperasi memiliki nilai resiko sebesar 55\%. Hal ini dikarenakan sifat susu sapi yang mudah rusak, maka diperlukan perlakuan yang lebih intensif dalam melakukan proses rantai pasokan susu sapi mulai dari perencanaan hingga pengiriman.

Pada atribut kinerja cost Koperasi Peternak Galur Murni dalam melaksanakan kegiatan rantai pasokannya selama satu tahun dan memasarkan susu sapi dan produk olahan sebanyak 356.160 liter, mengeluarkan biaya mulai dari biaya penyampaian material, biaya produksi, dan biaya pemenuhan pesanan sebesar Rp 783.484.828,00. Tingginya biaya pemenuhan pesanan ini dikarenakan biaya pengemasan yang tinggi. hal ini menunjukkan bahwa kinerja pada atribut cost masih belum baik.

Atribut kinerja Assets merupakan atribut kinerja yang mengukur kemampuan rantai pasokan dalam mengelola aset yang dimiliki seefisien mungkin. Pada atribut kinerja Assets terdiri dari indikator siklus cash-to-cash, indikator pengembalian aset tetap rantai pasokan, dan indikator pengembalian modal kerja menunjukkan bahwa kinerja koperasi masih belum baik. Pada indikator siklus cash-to-cash pada Koperasi Peternak Galur Murni memerlukan waktu selama 22 hari sejak pertama kali mengeluarkan biaya untuk pengadaan susu sapi yang kemudian diproses hingga menerima pembayaran atas produk susu sapi yang diproduksi serta stok susu sapi yang disimpan. Lamanya waktu penerimaan yang diperoleh oleh koperasi dikarenakan sistem pembayaran yang dilakukan pada penjualan susu sapi dan produk olahan adalah secara berkala yang dilakukan oleh PT. Nestle cukup lama yaitu 10 hari dan konsinyasi yang dilakukan poleh pedagang pengecer. Pada indikator pengembalian asset koperasi mampu mengembalikan 14,76\% biaya yang dialokasikan untuk pembelian asset tetap, sehingga dalam pengembalian modal investasi membutuhkan waktu lebih lama. Rendahnya pengembalian tersebut dipengaruhi oleh keuntungan yang dihasilkan dan mahalnya harga peralatan processing susu. Pada indikator pengembalian modal kerja sebesar $30,75 \%$, rendahnya nilai tersebut dipengaruhi oleh keuntungan yang dihasilkan.

\section{Nilai Tambah Pengolahan Susu Sapi Perah di Koperasi Peternak Galur Murni}

Nilai tambah adalah suatu perubahan nilai yang terjadi karena adanya perlakuan terhadap suatu input pada suatu proses produksi. Arus peningkatan nilai tambah komoditas pertanian terjadi di setiap mata rantai pasok dari hulu ke hilir yang berawal dari petani dan berakhir pada konsumen akhir. (Marimin dan Maghfiroh, 2010). Nilai tambah yang dikaji dalam penelitian ini adalah nilai tambah pada Koperasi Peternak Galur Murni yaitu pengolahan susu sapi menjadi produk olahan susu pasteurisasi dan yoghurt. Hal ini, dikarenakan susu sapi memiliki karakteristik mudah 
rusak, sehingga tidak memiliki masa simpan yang lama dan harus diberi penangan khusus agar produk susu sampai ketangan konsumen dalam keadaan baik

Berdasarkan Tabel 3 hasil analisis nilai tambah pengolahan susu sapi menjadi susu pasteurisasi dan yoghurt pada Koperasi Peternak Galur Murni di Kecamatan Sumberbaru Kabupaten Jember, menghasilkan nilai tambah positif. Olahan susu sapi di Koperasi Peternak Galur Murni memberikan nilai tambah berupa susu pasteurisasi sebesar Rp 5.194,39 dengan rasio sebesar $28.86 \%$ dan olahan yoghurt sebesar Rp 7.987,78 dengan rasio sebesar 36.31\%. Hal ini menunjukkan bahwa nilai tambah olahan yoghurt lebih besar dibandingkan dengan olahan susu pasteurisasi. Nilai tambah merupakan hasil pengurangan dari nilai produk dan biaya intermediate. Nilai tambah yoghurt lebih besar dikarenakan harga jual produk yoghurt lebih tinggi yaitu Rp. 22.000,00 dibandingkan dengan harga susu pasteurisasi sebesar Rp. $18.000,00$. Nilai produk diperoleh dari hasil kali antara harga jual produk dengan faktor konversi. Faktor konversi yoghurt dan susu pasteurisasi sebesar 1,00 dimana faktor konversi diperoleh dari pembagian nilai output dengan nilai input bahan baku untuk setiap 1 liter susu segar. Koefisien tenaga kerja pada rantai pasok susu sapi dihitung berdasarkan Harian Kerja Pria (HKP).

Rendahnya nilai tambah susu pasteurisasi juga dipengaruhi oleh biaya intermediate. Biaya intermediate diperoleh dari hasil bagi antara total biaya selain tenaga kerja dengan jumlah bahan baku. Namun, permintaan konsumen terhadap produk olahan susu pasteurisasi lebih banyak dibandingkan olahan yoghurt.

Tabel 3. Nilai Tambah Per Liter Bahan Baku pada Olahan Susu Sapi di Koperasi Peternak Galur Murni Kecamatan Sumberbaru Kabupaten Jember

\begin{tabular}{clrr}
\hline No & \multicolumn{1}{c}{ Analisis Nilai Tambah } & Susu Pasteurisasi & \multicolumn{1}{c}{ Yoghurt } \\
\hline 1 & Output (liter/proses produksi) & 20,00 & 15,00 \\
2 & Input bahan baku (liter/proses produksi) & 20,00 & 15,00 \\
3 & Input tenaga kerja (HKP/proses produksi) & 1,00 & 1,00 \\
4 & Faktor konversi & 1,00 & 1,00 \\
5 & Koefisien tenaga kerja (HKP/liter) & 0,05 & 0,07 \\
6 & Harga produk (Rp/liter) & $18.000,00$ & $22.000,00$ \\
7 & Upah tenaga kerja (Rp/HKP) & $50.000,00$ & $50.000,00$ \\
\hline \multicolumn{4}{c}{ Penerimaan dan keuntungan per liter susu sapi } \\
\hline 8 & Intermediet Cost & & \\
& a. Susu sapi perah (Rp/proses produksi) & $90.000,00$ & $67.500,00$ \\
& b. Biaya bahan penolong (Rp/proses produksi) & $49.000,00$ & $22.000,00$ \\
& c. Biaya bahan bakar (Rp/proses produksi) & $11.600,00$ & $11.600,00$ \\
& d. Biaya pengemasan (Rp/proses produksi) & $57.000,00$ & $60.000,00$ \\
& e. Biaya penunjang (Rp/proses produksi) & $18.750,00$ & $18.750,00$ \\
& f. Biaya penyusutan alat (Rp/proses produksi) & $29.762,15$ & $30.333,33$ \\
& Biaya total selain biaya TK (Rp/proses produk- & $256.112,15$ & $210.183,33$ \\
& si) & & \\
Nilai IC (Rp/liter) & $12.806,61$ & $14.012,22$ \\
9 & Nilai produk (Rp/liter) & $18.000,00$ & $22.000,00$ \\
10 & a. Nilai tambah (Rp/liter) & $5.194,39$ & $7.987,78$ \\
& b. Rasio nilai tambah (\%) & 28,86 & 36,31 \\
11 & a. Pendapatan tenaga kerja (Rp/liter) & $2.500,00$ & $3.333,33$ \\
& b. Pangsa tenaga kerja (\%) & 48,13 & 41,73 \\
12 & a. Keuntungan (Rp/liter) & $2.694,39$ & $4.654,44$ \\
& b. Rasio keuntungan (\%) & 14.97 & 21,16 \\
\hline
\end{tabular}

Sumber: Data Primer diolah Tahun 2015 
dapat dilihat pada hasil output olahan susu pasteurisasi sebesar 20 liter dan olahan yoghurt sebesar 15 liter. Nilai tambah dan keuntungan yang dihasilkan lebih kecil dibandingkan dengan upah tenaga kerja per liter susu sapi, yang artinya kegiatan pengolahan susu sapi menjadi susu pasteurisasi dan yoghurt pada Koperasi Peternak Galur Murni merupakan kegiatan padat karya. Dengan kata lain, pelaksanaan produksi olahan susu tidak memerlukan tambahan tenaga kerja lagi atau tidak ada kesempatan kerja untuk tambahan pada kegiatan ini. Oleh karena itu untuk meningkatkan nilai tambah pada produk olahan susu pasteurisasi dan yoghurt yaitu dengan mengurangi intermediet cost (selain tenaga kerja) dan memaksimalkan kuantitas dan kualitas setiap produk olahan.

\section{KESIMPULAN}

1. Manajemen rantai pasok susu sapi perah di Koperasi Peternak Galur Murni Kecamatan Sumberbaru Kabupaten Jember memiliki tiga aliran yaitu aliran produk, aliran keuangan dan aliran informasi. Aliran produk dalam rantai pasokan susu sapi perah di Koperasi Peternak Galur Murni dapat dibedakan menjadi dua macam aliran, yaitu aliran produk berupa susu sapi (segar) dan aliran olahan susu sapi. Aliran keuangan dalam rantai pasok susu sapi perah mengalir dari konsumen akhir sampai ke peternak. Aliran ini dibedakan menjadi enam macam aliran dengan sistem pembayaran tunai, kredit, berkala dan konsinyasi. Aliran informasi dalam rantai pasokan susu sapi perah di Koperasi Peternak Galur Murni terbagi menjadi dua macam aliran, yaitu aliran informasi secara horizontal dan aliran informasi secara vertikal.

2. Koperasi Peternak Galur Murni merupakan focal firm atau lembaga yang menjadi fokus dalam sistem manajemen rantai pasokan. Pengukuran kinerja rantai pasokan susu sapi perah di Koperasi Peternak Galur Murni pada lima atribut kinerja menghasilkan nilai yang berbeda-beda. Koperasi Peternak Galur Murni memiliki kinerja yang baik pada atribut Reliability dan atribut Responsiveness. Pada atribut Agility, Costs, dan Assets menunjukkan kinerja yang belum baik dikarenakan nilai dari masing-masing indikator perhitungan belum sempurna.

3. Koperasi Peternak Galur Murni mampu memberikan nilai tambah positif dalam bentuk olahan susu pasteurisasi sebesar Rp. $5.194,39$ dengan rasio sebesar 28,86\% dan olahan yoghurt sebesar Rp. 7.987,78 dengan rasio sebesar $36,31 \%$.

\section{DAFTAR PUSTAKA}

AAK. 2012. Sapi Perah. Yogyakarta: Kanisius.

Arjakusuma, R. S., Sri, H., dan Idqan, F. 2013. Rantai Nilai pada Industri Susu: Studi Kasus PT.Cisarua Mountain Dairy (Cimory). Manajemen dan Agribisnis,10 (1): 2231.

Marimin dan Maghfiroh, N. 2010. Aplikasi Teknik Pengambilan Keputusan dalam Manajemen Rantai Pasok. Bogor: IPB Press.

Misgiyarta, A. Budiyanto dan R. Sunarlim. 2008. Pengaruh Lama Waktu Transportasi Susu Segar terhadap Tingkat Kontaminan Mikrob (Studi Kasus di Wilayah KUD Sarwamukti, Lembang, Jawa Barat). Seminar Nasional Teknologi Peternakan dan Veteriner, Bogor, pp. 264-270.

Nazir, Moh. 2005. Metode Penelitian. Ciawi: Ghalia Indonesia.

Septani, W., Syamsul, M., dan Yandra, A. 2013. Manajemen Risiko Inovasi Produk Olahan Susu Sapi Berdasarkan Tahapan Proses Manajemen Inovasi. Jurnal Teknik Industri, 3 (2):169-178.

Sudiyono, A. 2002. Pemasaran Pertanian. Malang: Universitas Muhammadiyah Malang.

Supply Chain Council. 2012. SCOR (Supply Chain Operations Reference-Model). America: SCC.

Usmiati, S dan Abubakar. 2009. Teknologi Pengolahan Susu. Bogor: Balai Besar Penelitian dan Pengembangan Pascapanen Pertanian.

Wirawan, O. A. 2015. Peternakan sapi perah di Jember hadapi persoalan.[serial online]. http://Peternakan Sapi Perah di Jember Hadapi Persoalan- beritajatim.com.htm\#. 
VouDkfB8qKI. Diakses tanggal 22 September 2015 . 